\title{
Habitat amount modulates the effect of patch isolation on host-parasitoid interactions
}

\author{
Valérie Coudrain ${ }^{1,2,3}{ }^{*}$, Christof Schüepp ${ }^{2,3}$, Felix Herzog ${ }^{1}$, Matthias Albrecht ${ }^{1}$ and Martin H. Entling ${ }^{3}$ \\ ${ }^{1}$ Agricultural Landscapes and Biodiversity, Agroscope, Zürich, Switzerland \\ 2 Institute of Ecology and Evolution, Department of Community Ecology, University of Bern, Bern, Switzerland \\ ${ }^{3}$ Institute for Environmental Sciences, Department of Ecosystem Analysis, University of Koblenz-Landau, Landau/Pfalz, Germany
}

Edited by:

Eike Luedeling, World Agroforestry

Centre, Kenya

Reviewed by:

María Silvina Fenoglio, Consejo

Nacional de Investigaciones

Científicas y Técnicas, Argentina

Evan Hartunian Girvetz, International

Center for Tropical Agriculture,

Kenya

\section{*Correspondence:}

Valérie Coudrain, Research Center Agroscope, Reckenholzstrasse 191, 8046 Zürich, Switzerland e-mail:vcoudrain@gmail.com
Habitat amount and patch isolation are important determinants of biodiversity and ecosystem functioning. We studied the separate and interactive effects of these two components of habitat fragmentation on host-parasitoid interactions in a replicated landscape-scale study. We used trap-nesting solitary bees, wasps and their natural enemies as study system. We exposed trap nests in 30 tree patches in agricultural landscapes in northern Switzerland. Study sites were either (i) adjacent to forest (adjacent), (ii) distant from forest but connected through woody elements (connected) or (iii) distant from forest with no connecting woody elements (isolated). Independent of the three levels of isolation, the amount of woody habitat in the landscapes covered a gradient from 4 to $74 \%$. Host and parasitoid species richness increased with the amount of habitat in the landscape and was strongly reduced at isolated compared to adjacent and connected sites. Loss of host species richness was $21 \%$ at isolated compared to non-isolated sites, whereas parasitoid species richness decreased by $68 \%$, indicating that the higher trophic level was more adversely affected by isolation. Most importantly, habitat amount and isolation had a pronounced interactive effect on parasitism: while isolation resulted in a strong decrease in parasitism in landscapes with low habitat amount, this effect was mitigated by high habitat amount. These interactive effects were consistent across the three years of the study. The observed interplay between habitat amount and patch isolation may explain the often conflicting results in the habitat fragmentation literature and should be considered in future research on multitrophic communities and ecosystem functioning in fragmented landscapes.

Keywords: connectivity, habitat fragmentation, Hymenoptera, landscape ecology, multitrophic interactions, solitary bee

\section{INTRODUCTION}

Habitat fragmentation can affect the diversity of species and disrupt their interactions (Aizen et al., 2012; Hagen et al., 2012; Ferreira et al., 2013; Rösch et al., 2013), with consequences for ecosystem service provisioning (Kruess and Tscharntke, 1994; Staddon et al., 2010; Tylianakis, 2013; Schüepp et al., 2014a,b). However, our understanding of the impact of fragmentation on ecological communities and the functional consequences for ecosystems suffers from major gaps (Tscharntke et al., 2012). Fragmentation consists of habitat loss and fragmentation per se, the latter defined as the breakdown of core habitat into isolated patches (Fahrig, 2003). Separating the consequences of patch isolation from that of habitat loss in the landscape is a challenge in empirical studies (Tscharntke et al., 2012). Yet, such an approach may be key for advancing our understanding of biodiversity and ecosystem functioning in a fragmented world (Farwig et al., 2009; Hadley and Betts, 2011; Mortelliti et al., 2011; With and Pavuk, 2011; Herrera and Doblas-Miranda, 2013). In particular, potential interactive effects among habitat loss and isolation on trophic interactions remain largely unexplored (Herrera and Doblas-Miranda, 2013). Visser et al. (2009) modeled such interactive effects for a simple host-parasitoid system, predicting interactions on parasitoid persistence, whereas parasitism should be primarily negatively affected by isolation, regardless of habitat amount. In contrast to these predictions, Fahrig (2013) posits that ecological responses at the patch level should be essentially driven by the amount of habitat within the landscape, irrespective of patch isolation and size (habitat amount hypothesis). Because species at higher positions in the food chain may be particularly vulnerable to habitat loss (Holt et al., 1999; Kruess and Tscharntke, 2000; Cagnolo et al., 2009; Valladares et al., 2012), species richness of parasitoids should increase strongly with the amount of habitat in a landscape, even if the size of the sampled habitat patch is constant (Fahrig, 2013). If higher parasitoid diversity leads to higher parasitism rate (e.g., Tylianakis et al., 2006; Fenoglio et al., 2012), negative effects of isolation on parasitism rate, as predicted by Visser et al. (2009), may be mitigated by higher habitat amount within the landscape. As a result, decline in parasitism rate with isolation should be more pronounced in simple, habitat-poor landscapes compared to more complex 
landscapes with high habitat amount. Here, we investigated the separate and interactive effects of habitat amount and isolation on the trophic interactions of trap-nesting bees and wasps with their parasitoids over three years. In particular, we tested the following hypotheses:

1) Species richness and abundance in host-parasitoid communities increase with increasing habitat amount within the landscape and are lower in isolated compared to adjacent and connected patches. Patterns are more pronounced for the higher compared to the lower trophic level.

2) Parasitism is reduced in isolated patches and in habitat patches surrounded by low amount of habitat as a result of reduced parasitoid species richness and abundance.

3) High habitat amount mitigates adverse effects of patch isolation on host and parasitoid diversity and on parasitism.

\section{MATERIALS AND METHODS STUDY SITES AND EXPERIMENTAL DESIGN}

The study was conducted on the Swiss Plateau between the cities of Bern, Solothurn and Fribourg, a region that is dominated by agriculture interspersed with forest patches. Thirty experimental sites were chosen over an area of $23 \times 32 \mathrm{~km}$ varying in altitude between 465 and $705 \mathrm{~m}$ above sea level (Figure 1). The sites were selected according to the amount of woody habitat (forests, hedgerows and orchards) within a $500 \mathrm{~m}$ radius (ranging from 4 to $74 \%$ woody habitat). Circles of $500 \mathrm{~m}$ radius were chosen because (i) this scale is considered to roughly match the activity range of the studied organisms (e.g., Gathmann and Tscharntke, 2002; Zurbuchen et al., 2010) and (ii) they correspond to the rather fine "grain" of the landscape of that region, i.e., the smallscaled mosaic of woody and agricultural landscape elements. The second selection criterion was isolation of the sites from woody habitat (Figure 2):

- Ten sites were located adjacent to forest (adjacent);

- ten sites were located at a distance of 100-200 m from the next forest, but next to woody elements such as hedgerows or rows of single trees that partly filled the interspace between study site and forest (connected);

- ten sites were located at least $100 \mathrm{~m}$ away from any woody habitat (isolated).

We distinguished among adjacent and connected sites because of the structural properties of the adjoining woody habitat. Forest had a closed canopy and no gaps between the shaded areas, while the connecting small-sized woody elements had gaps of open habitat between trees and shrubs, as did our study sites. Information on woody habitats was derived from official digital land-use maps (vector25, swisstopo, Wabern) and verified using aerial photographs and field inspection. There was no statistical dependency between the percentage of woody habitat in a landscape sector and the level of isolation of a study site $\left[F_{(2,27)}=\right.$ $0.004, P=0.99$ ]. The distance to the nearest forest was similar among isolated and connected sites (isolated: $128.5 \pm 31.7 \mathrm{~m}$, connected: $147.7 \pm 41.6 \mathrm{~m}$ ). The $500 \mathrm{~m}$-radius landscape sectors

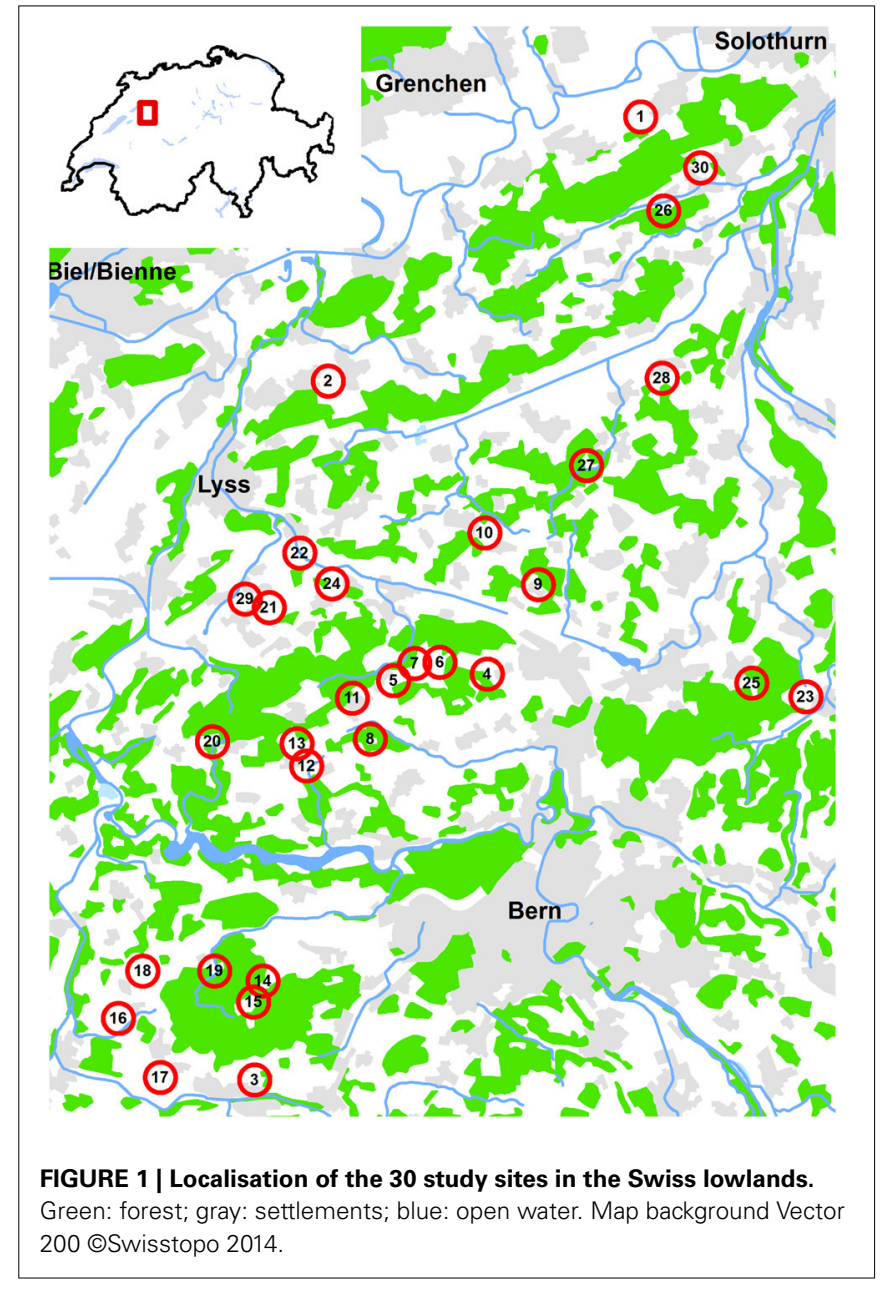

surrounding the study sites were located at least $750 \mathrm{~m}$ apart to minimize potential spatial autocorrelation. In order to standardize the habitat type in which the investigations were to be conducted, at each site we planted an $18 \mathrm{~m}$-long row of young cherry trees on permanent grassland in spring 2008. Since then, the study sites were managed in a standardized manner (Schüepp et al., 2011).

In other words, within the $500 \mathrm{~m}$ landscape circles, we measured at adjacent, connected and isolated locations but on artificially introduced, standardized cherry tree rows as habitat patches.

\section{STUDY SYSTEM}

In mid-March 2008, four trap nests for solitary bees and wasps were set up in each habitat patch on wooden posts $1 \mathrm{~m}$ above ground. Two traps were placed at $6 \mathrm{~m}$ distance from each end of each experimentally established tree row. Trap-nests consisted of plastic cylinders filled with an average of 180 tubes of common reed (Phragmites australis L.), with diameters ranging from 2 to $10 \mathrm{~mm}$ and the same proportion of each diameter in every trap. Each year from 2008 to 2010 two of the four trap nests were removed in October to analyse wasp and bee communities, and two were left in the field to allow for local population 

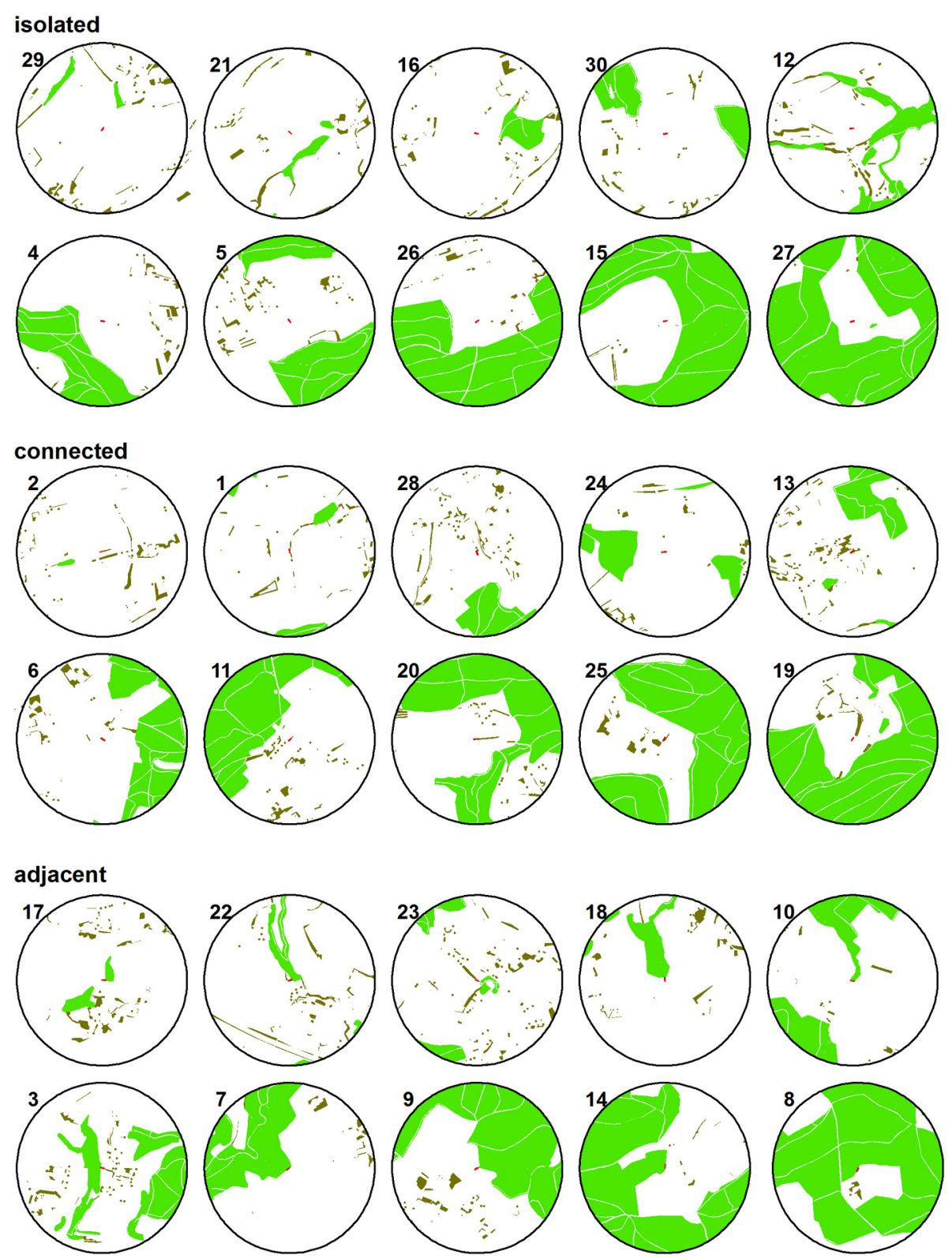

FIGURE 2 | Simplified maps of the study sites. Their numbers relate to Figure 1. Light green: forest; dark green: small woods; red: study sites at the center of the $500 \mathrm{~m}$ radius circles.

development over these three consecutive years. Removed trap nests were stored at $5^{\circ} \mathrm{C}$ from mid-October to mid-January, and occupied reed internodes were individually transferred into glass tubes. The glass tubes were left at room temperature $\left(22^{\circ} \mathrm{C}\right)$ for the emergence of adult bees, wasps and their natural enemies (enemies comprise parasitoids, cleptoparasites and predators, hereafter collectively referred as "parasitoids"). Emerged individuals were determined at the species level or, if not possible, at the genus or family level. In the cases where no adult hosts emerged, hosts were identified at the genus or family level based on the features of their breeding cells (Gathmann and Tscharntke, 1999). Host abundance was defined as the total number of brood cells per habitat patch and parasitoid abundance as the number of attacked brood cells. Parasitism rate was defined as the number of attacked brood cells divided by the total amount of brood cells.

The studied trap-nesting bees and wasp species are multihabitat users that depend on scattered resources to complete their life cycle. Besides suitable food resources, they require existing cavities to build their nests. Females lay their eggs in a series of brood cells provisioned with pollen and nectar (bees) or prey (wasps). Each cell is closed with mud or organic material and the completed nest is sealed with a plug of mud or resin (Gathmann and Tscharntke, 2002; Zurbuchen et al., 2010; Coudrain et al., 2013; Bailey et al., 2014). The breeding cells are attacked by a 
range of enemies ("parasitoids") from several families that feed on the developing offspring or its provisions (Gathmann and Tscharntke, 1999).

\section{STATISTICAL ANALYSES}

Generalized mixed models with Poisson error distribution and site as random factor were used to test the effect of habitat amount, isolation, year (as factor with tree levels) and their pair-wise interactions on host and parasitoid abundance and species richness. To investigate if abundance and species richness of parasitoids were more affected than that of their hosts (trophic-level hypothesis, Holt et al., 1999), trophic level (parasitoids vs. hosts) and its interaction with isolation and habitat amount was included in the generalized mixed models with Poisson error distribution. Significant interactions indicate different responses to isolation and habitat amount of the two trophic groups. Generalized mixed models with binomial error distribution and patch as random factor were used to test the effect of habitat amount, patch isolation, year and their pairwise interactions on parasitism. In the models with the response variables host abundance, parasitoid abundance and parasitism, an observation-level random effect was included to account for overdispersion (Elston et al., 2001; Browne et al., 2005). The amount of habitat was square-root-transformed to improve model fit. Model fit was visually assessed by plotting fitted versus residual values and Cook's distances were calculated to detect possible outliers. Models were compared based on chi-square tests and non-significant interactions sequentially removed. To gain a more mechanistic understanding of how fragmentation drives changes in parasitoids, i.e., to test whether the fragmentation treatment effects on parasitoid richness, parasitoid abundance and parasitism were mediated by host abundance or host species richness, the best models obtained were run again with either host abundance or host species richness as covariate entered before the treatment effects in the sequentially fitted models described above. Thus, we tested whether the variation explained by fragmentation (in the model without the co-variate host abundance or host species richness) is actually explained by the host covariate (host-mediated effects) and whether fragmentation effects still explain a significant part of the residual variation (not explained by the host covariate; direct effects not driven by host abundance or host species richness). All analyses were performed with $\mathrm{R}$ version 2.15.2 (R Development Core Team, 2011) using the additional package lme4 (Bates, 2012).

\section{RESULTS \\ SAMPLE SIZE}

A total of 41352 brood cells contained 10 bee, 28 wasp and about 50 enemy species from 21 families (Table 1 ).

\section{EFFECTS OF HABITAT AMOUNT AND PATCH ISOLATION}

Both host $(\mathrm{Chi}=10.3, P<0.01)$ and parasitoid $(\mathrm{Chi}=21.3$, $P<0.01)$ species richness were lower at isolated sites than at sites adjacent and connected to forest (Figures 3A,B). Host species richness was $21.4 \%$ resp. $24.3 \%$ higher at adjacent resp. connected sites compared to isolated sites, while parasitoid species richness was $68.5 \%$ resp. $64.3 \%$ higher. As predicted, the impact of isolation on species richness was significantly higher for parasitoids than for their hosts $(\mathrm{Chi}=7.56, P=0.02)$. Further, species richness of hosts $(\mathrm{Chi}=4.6, P=0.03)$ and parasitoids $(\mathrm{Chi}=3.9$, $P=0.05$ ) increased with increasing amount of woody habitat in the surrounding landscape, without significant difference in the rate of increase between the two trophic levels ( $\mathrm{Chi}=0.07, P=$ 0.79 ). There was no interactive effect of patch isolation and habitat amount on species richness of hosts $(\mathrm{Chi}=2.1, P=0.35)$ or parasitoids (Chi $=1.6, P=0.46)$. Parasitoid species richness was positively correlated with abundance and species richness of their hosts (Table 2). When including host abundance or host species richness as covariate before patch isolation and habitat amount, the effects of patch isolation on parasitoid species richness

Table 1 | Insect families and overall abundance of functional groups expressed as number of brood cells summed over the three treatments "adjacent" (a), "connected" (c), and "isolated" (i) over the three years investigated.

\begin{tabular}{|c|c|c|c|c|c|c|c|c|c|}
\hline Treatment & \multicolumn{3}{|c|}{2008} & \multicolumn{3}{|c|}{2009} & \multicolumn{3}{|c|}{2010} \\
\hline Host bee abundance & 196 & 396 & 374 & 2516 & 3010 & 2047 & 4709 & 5163 & 3279 \\
\hline
\end{tabular}

Bee parasitoid families Anobiidae, Bombyliidae, Braconidae, Cleridae, Chrysidae, Dermestidae, Drosophilidae, Eulophidae, Gasteruptionidae, Ichneumonidae, Megachilidae, Sapygidae, Torymidae

\begin{tabular}{lcccccccc}
\hline Bee parasitoid abundance & 13 & 37 & 14 & 591 & 657 & 409 & 989 & 980 \\
\hline Host wasp families & Crabronidae, Eumeninae, Pompilidae & & & & & \\
\hline Host wasp abundance & 1712 & 820 & 477 & 4240 & 2139 & 824 & 4066 & 2652 \\
\hline
\end{tabular}

Wasp parasitoid families

Bombyliidae, Braconidae, Cleridae, Chrysidae, Dermestidae, Drosophilidae, Encyrtidae, Eulophidae, Eurytomidae, Gasteruptionidae, Ichneumonidae, Pteromalidae, Sapygidae 

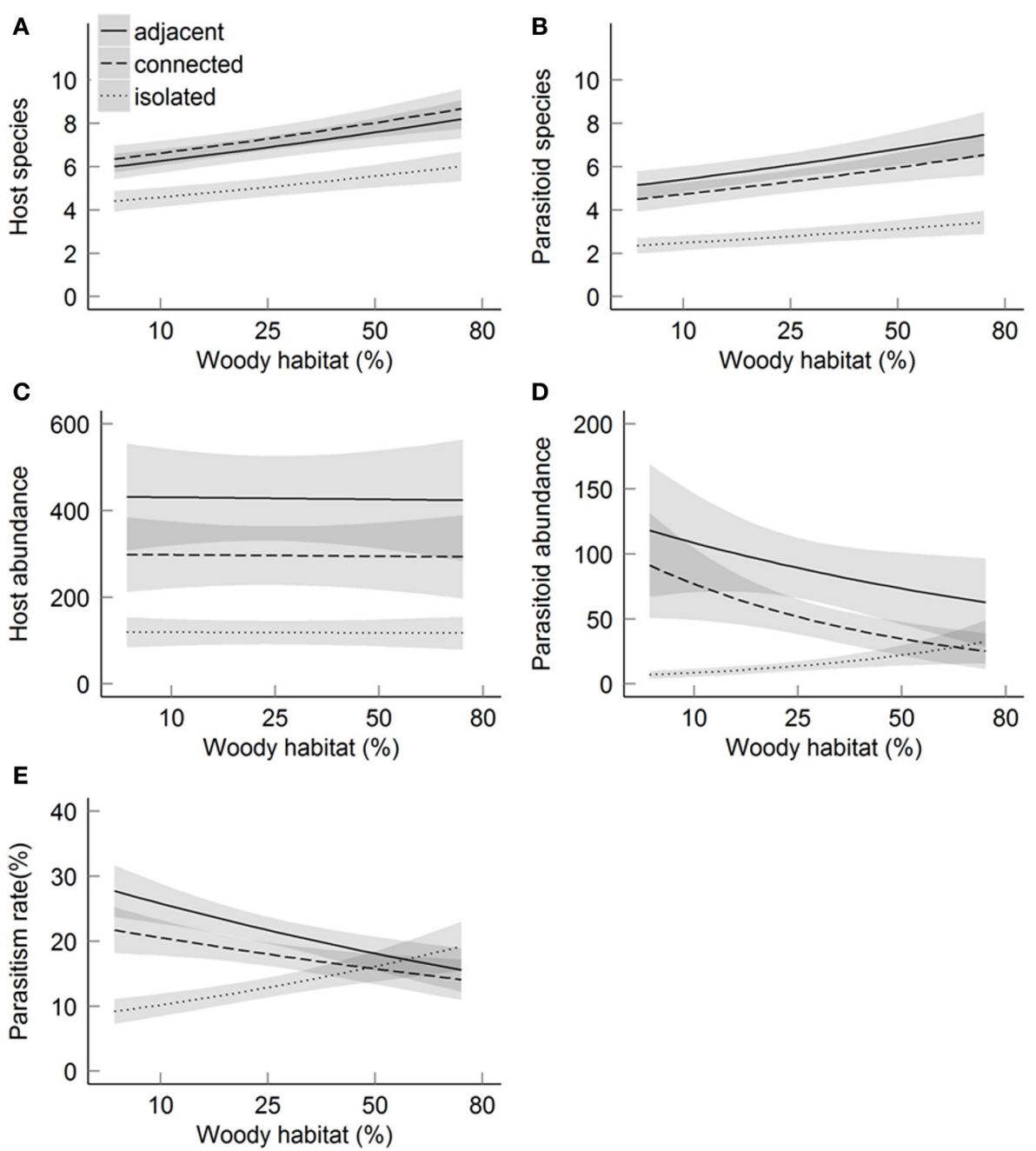

FIGURE 3 | Relationships between the amount of woody habitat within the landscape and host-parasitoid communities in function of the three levels of patch isolation. Host-parasitoid communities were described by the following response variables: number of host species (A), number of parasitoid species (B), host abundance (C),

parasitoid abundance (D) and parasitism rate (E). Solid and dashed lines indicate predicted values of best-fitting models. Gray shading indicates standard error predicted values. Predicted values are based on data from the three years of study, host abundance is not included as covariable.

remained significant. This indicates that, in addition to indirect effects mediated by host abundance and species richness, isolation also directly affected parasitoid species richness. In contrast, habitat amount was no longer significant when host species richness was included as a covariate, which suggests an indirect effect of habitat amount on parasitoid species richness as a byproduct of the impact of habitat amount on host species richness.

Host abundance was lower at isolated compared to connected and adjacent sites (19.0\% resp. $24.7 \%$ lower, Chi $=$ 13.4, $P<0.01)$, but it was not related to the amount of woody habitat (Chi $<0.1, P=0.95$; Figure $3 \mathrm{C}$ ). There was no significant interaction among patch isolation and habitat amount on host abundance (Chi $=1.6, P=0.46)$. In contrast to host abundance, there was an interactive effect of habitat amount and patch isolation on parasitoid abundance ( $\mathrm{Chi}=6.1, P=0.05$; Figure 3D). Moreover, there was a strong interactive effect of patch isolation and habitat amount on parasitism (Chi $=$
10.0, $P<0.01$; Figure 3E). Patch isolation negatively affected parasitoid abundance and parasitism at low habitat amount, but not at high habitat amount in the landscape. This effect was robust also after accounting for variation due to host abundance $(\mathrm{Chi}=9.2, P=0.01)$.

\section{TEMPORAL DYNAMICS}

Abundance of hosts and parasitoids increased during the years of the study, mainly from the first to second year (Table 3 ). The effects of patch isolation, habitat amount and their interaction on these response variables were consistent over the three years of the study (interactions with year: all $P \geq 0.18$ ).

\section{DISCUSSION}

Our 3-year study demonstrates divergent effects of landscape habitat amount and patch isolation on different trophic levels of host-parasitoid communities, thereby altering parasitism rates. 
Table 2 | Pearson correlation coefficients between host and parasitoid species richness and abundance and parasitism.

\begin{tabular}{lcccc}
\hline & $\begin{array}{c}\text { Host species } \\
\text { richness }\end{array}$ & $\begin{array}{c}\text { Parasitoid } \\
\text { abundance }\end{array}$ & $\begin{array}{c}\text { Parasitoid } \\
\text { species } \\
\text { richness }\end{array}$ & Parasitism \\
\hline $\begin{array}{l}\text { Host abundance } \\
\text { Host species }\end{array}$ & $0.35^{*}$ & $0.85^{*}$ & $0.66^{*}$ & 0.18 \\
$\begin{array}{l}\text { richness } \\
\text { Parasitoid }\end{array}$ & $0.29^{*}$ & $0.60^{*}$ & $0.26^{*}$ \\
$\begin{array}{l}\text { abundance } \\
\text { Parasitoid } \\
\text { species richness }\end{array}$ & & $0.61^{*}$ & 0.54 \\
\hline
\end{tabular}

Significant correlations $(p<0.05)$ are indicated by *.

Table 3 | Results of pairwise differences between years (GLMM with Poisson or binomial distribution and site and individual observation as random effects).

\begin{tabular}{|c|c|c|c|c|c|c|}
\hline & \multicolumn{3}{|c|}{ 2008-2009 } & \multicolumn{3}{|c|}{ 2009-2010 } \\
\hline & Estimate & Chi & $\boldsymbol{P}$ & Estimate & Chi & $P$ \\
\hline Host abundance & 1.282 & 40.58 & $<0.01$ & 0.241 & 3.72 & 0.054 \\
\hline $\begin{array}{l}\text { Parasitoid } \\
\text { abundance }\end{array}$ & 1.867 & 56.25 & $<0.01$ & 0.267 & 4.76 & 0.029 \\
\hline $\begin{array}{l}\text { Host species } \\
\text { richness }\end{array}$ & 0.356 & 11.51 & $<0.01$ & 0.028 & 0.08 & 0.772 \\
\hline $\begin{array}{l}\text { Parasitoid } \\
\text { species richness }\end{array}$ & 0.461 & 13.25 & $<0.01$ & 0.114 & 1.08 & 0.298 \\
\hline Parasitism & 0.678 & 13.02 & $<0.01$ & -0.030 & 0.03 & 0.82 \\
\hline
\end{tabular}

Significant results are highlighted in bold.

We found pronounced effects of patch isolation on species richness with the higher trophic level being more adversely affected than the lower one. Consistent over years, parasitism was reduced by patch isolation in landscapes with low habitat amount, but remained unaffected by isolation in habitat-rich landscapes.

Both habitat amount and isolation were important drivers of host and parasitoid species richness at a given site. Since an increase in patch isolation can be a by-product of habitat loss within the landscape (Fahrig, 2003), apparent isolation effects may simply result from lower species pool in the surrounded habitat ("sample area effect," Fahrig, 2013). However, by empirically separating habitat amount from isolation, we show that isolation per se can negatively affect species richness. In the studied host-parasitoid communities, the estimated loss of host species was $21 \%$ and that of parasitoids even $68 \%$ at isolated compared to both connected and wood-adjacent sites, challenging the view that habitat amount is the predominant driver of fragmentation effects (habitat amount hypothesis; Fahrig, 2013). As parasitoids can be both directly and indirectly (via changed host abundance or richness) affected by habitat amount and isolation, we calculated all models with and without host parameters as covariables. The significant reduction of parasitoids at isolated sites even when accounting for hosts indicates direct negative effect of isolation on parasitoids. In contrast, the increase of parasitoid richness by habitat amount became non-significant when accounting for host richness and may thus be a purely indirect consequence of reduced host richness in landscapes with low amounts of habitat. Separate effects of landscape habitat amount and patch isolation further indicate that at least two mechanisms contributed to the species richness of the studied communities. First, landscape habitat amount should relate to the species pool that sets the number of species available to colonize a habitat patch, and second, isolation acts as an ecological filter, such that only reduced numbers of species and individuals colonize isolated habitat patches. Limited dispersal of host species, including some of the most abundant species such as the spider-hunting wasp Trypoxylon figulus (L.), which strongly declined at isolated compared to adjacent and connected sites, is probably also the main factor explaining reduced host abundance at isolated sites. Other possible explanations such as limited food resources for offspring production (e.g., Stamp, 2001) or top down pressures by parasitoids could be excluded in a recent study focusing on T. figulus as a model species (Coudrain et al., 2013). Indeed, strongly reduced parasitism rates at isolated sites would rather suggest a release of top down pressure rather than an increase (Kruess and Tscharntke, 1994; Herrmann et al., 2012; Schüepp et al., 2014b).

\section{INTERACTIVE EFFECTS OF LANDSCAPE AMOUNT AND PATCH ISOLATION}

Our results support theoretical predictions that parasitism decreases with patch isolation (Visser et al., 2009). However, we found pronounced and temporally consistent interactive effects of habitat amount and isolation on parasitoid abundance and parasitism rates. This interaction exceeds previous theoretical predictions and empirical findings. Thus the effect of patch isolation on interactions depended on the amount of habitat within the landscape. At the community level, ecological functions emerge from the interactions among multiple species (Sih et al., 1998; Kremen et al., 2007; Tylianakis et al., 2007). Therefore, changes in species richness and abundance following landscape fragmentation can induce shifts in parasitism that are unpredicted from a two species-host-parasitoid system. Moreover, the equal dispersal ability of hosts and parasitoids assumed by Visser et al. (2009) may be rather exceptional in host-parasitoid communities (e.g., Van Nouhuys and Hanski, 2002; Elzinga et al., 2007; Sivakoff et al., 2012).

Higher parasitism can result from higher parasitoid richness (Tylianakis et al., 2006; Ebeling et al., 2011; Fenoglio et al., 2012; but see Rodriguez and Hawkins, 2000). Thus, high amounts of habitat may mitigate negative isolation effect on parasitism by enhancing parasitoid species richness. Particularly when prey resources are scarce, inter-specific complementarity in prey exploitation should be maximized (Griffin et al., 2008; Tylianakis and Romo, 2010). In accordance, we observed a parallel increase in parasitoid species richness and parasitism rate with increasing amount of habitat at isolated sites where host density was low. However, parasitism decreased with the amount of woody habitat and with parasitoid richness at forest-adjacent and connected sites where host abundance was high. Thus, other drivers than parasitoid diversity must have caused the decrease 
of parasitism with increasing habitat amount in forest-adjacent and connected situations (see also Table 2: parasitism rate correlates with parasitoid abundance and richness, but less so with host abundance and richness). A possible explanation is that high amounts of habitat complicate host finding by the parasitoids. This may especially be true in our system in which the two most abundant host species, Osmia bicornis (L.) and T. figulus, nest in woody habitat but also forage in more open habitats (Coudrain et al., 2013). Therefore, impaired host finding success of parasitoids may release host from parasitism in complex landscapes (Gols et al., 2005; Tylianakis et al., 2007; Laliberté and Tylianakis, 2010). Additionally, a larger number of natural cavities in habitat patches surrounded by higher amount of woody habitat may have diluted parasitoid attacks on trap-nesting host individuals. Parasitoid attacks could also be reduced through better defensive strategy of aggregated hosts (Rosenheim, 1990; Rohlfs and Hoffmeister, 2004; Steffan-Dewenter and Schiele, 2008), but in our studied community, parasitism rate changed irrespective of host abundance.

Hillebrand and Cardinale (2004) provide an alternative explanation for the decrease in parasitism rate at habitat-adjacent and connected sites. They show that in contrast to parasitoid species richness, a high host species richness often implies lower parasitism rate, which is mediated e.g., by the occurrence of inedible prey or temporal inconsistency among host and parasitoid flying period. Thus, as host species richness increased with amount of woody habitat, this could explain the decrease in parasitism in connected and forest-adjacent habitats. However, the positive correlation of parasitism to host species richness lends no support to this mechanism in our study system. In summary, a positive influence of parasitoid richness at isolated sites acting in concert with impaired host finding by parasitoids in connected and forest-adjacent patches could underlie the observed modulating action of habitat amount on the relationship between parasitism and patch isolation.

\section{IMPLICATIONS}

Our study demonstrates a pronounced interactive effect between habitat amount and isolation on higher trophic level species and trophic interactions. We found that high habitat amount in a landscape can mitigate negative effects of isolation on the strength of trophic interactions. Our findings provide a possible explanation for the variable outcomes of previous studies investigating the impacts of fragmentation per se (e.g., Fahrig, 2003; Ewers and Didham, 2006). From a conservation perspective, a further important finding is that patches connected to small, mostly linear woody habitats showed consistently similar levels of biodiversity and ecosystem functioning (parasitism) as patches adjacent to forest. This suggests that corridors of woody habitat can effectively promote connectivity in the studied agricultural landscapes.

\section{ACKNOWLEDGMENTS}

We thank Stephan Bosshart, Roman Bucher, Sandra Krause, Sarah Rittiner, and Deniz Uzman for their practical help and constructive comments. We thank the experts who helped in insect determination: Felix Amiet, Hannes Baur, Patrick Burguet, Mike
Hermann, Irene Salzmann and Martin Schwarz. We are grateful to the 30 farmers that provided their land for our experiments, to two anonymous reviewers for helping us to improve the manuscript and to Erich Szerencsits for artwork on the maps. This study was funded by the Swiss National Science foundation under grant number 3100A0-114058 to Felix Herzog and Martin Entling.

\section{REFERENCES}

Aizen, M. A., Sabatino, M., and Tylianakis, J. M. (2012). Specialization and rarity predict nonrandom loss of interactions from mutualist networks. Science 335, 1486-1489. doi: 10.1126/science. 1215320

Bailey, S., Requier, F., Nusillard, B., Roberts, S. P. M., Potts, S. G., and Bouget, C. (2014). Distance from forest edge affects bee pollinators in oilseed rape fields. Ecol. Evol. 4, 370-380. doi: 10.1002/ece3.924

Bates, D. (2012). Computational Methods for Mixed Models. [Tech. Rep.]. Madison, WI: Dept. of Statistics, University of Wisconsin.

Browne, W. J., Subramanian, S. V., Jones, K., and Goldstein, H. (2005). Variance partitioning in multilevel logistic models that exhibit overdispersion. J. R. Stat. Soc. Ser. A Stat. Soc. 168, 599-613. doi: 10.1111/j.1467-985X.2004.00365.x

Cagnolo, L., Valladares, G., Salvo, A., Cabido, M., and Zak, M. (2009). Habitat fragmentation and species loss across three interacting trophic levels: effects of lifehistory and food-web traits. Conserv. Biol. 23, 1167-1175. doi: 10.1111/j.15231739.2009.01214.x

Coudrain, V., Herzog, F., and Entling, M. H. (2013). Effects of habitat fragmentation on abundance, larval food and parasitism of a spider-hunting wasp. PLoS ONE 8:e59286. doi: 10.1371/journal.pone.0059286

Ebeling, A., Klein, A.-M., Weisser, W. W., and Tscharntke, T. (2011). Multitrophic effects of experimental changes in plant diversity on cavity-nesting bees, wasps, and their parasitoids. Oecologia 169, 453-465. doi: 10.1007/s00442-011-2205-8

Elston, D. A., Moss, R., Boulinier, T., Arrowsmith, C., and Lambin, X. (2001). Analysis of aggregation, a worked example: numbers of ticks on red grouse chicks. Parasitology 122, 563-569. doi: 10.1017/S0031182001007740

Elzinga, J. A., Van Nouhuys, S., Van Leeuwen, D.-J., and Biere, A. (2007). Distribution and colonisation ability of three parasitoids and their herbivorous host in a fragmented landscape. Basic Appl. Ecol. 8, 75-88. doi: 10.1016/j.baae.2006.04.003

Ewers, R. M., and Didham, R. K. (2006). Confounding factors in the detection of species responses to habitat fragmentation. Biol. Rev. 81, 117-142. doi: $10.1017 /$ S1464793105006949

Fahrig, L. (2003). Effects of habitat fragmentation on biodiversity. Annu. Rev. Ecol. Syst. 34, 487-515. doi: 10.1146/annurev.ecolsys.34.011802.132419

Fahrig, L. (2013). Rethinking patch size and isolation effects: the habitat amount hypothesis. J. Biogeogr. 40, 1649-1663. doi: 10.1111/jbi.12130

Farwig, N., Bailey, D., Bochud, E., Herrmann, J. D., Kindler, E., Reusser, N., et al. (2009). Isolation from forest reduces pollination, seed predation and insect scavenging in Swiss farmland. Landsc. Ecol. 24, 919-927. doi: 10.1007/s10980009-9376-2

Fenoglio, S. M., Srivastava, D., Valladares, G., Cagnolo, L., and Salvo, A. (2012). Forest fragmentation reduces parasitism via species loss at multiple trophic levels. Ecology 93, 2407-2420. doi: 10.1890/11-2043.1

Ferreira, P. A., Boscolo, D., and Viana, B. F. (2013). What do we know about the effects of landscape changes on plant-pollinator interaction networks? Ecol. Indic. 31, 35-40. doi: 10.1016/j.ecolind.2012.07.025

Gathmann, A., and Tscharntke, T. (1999). Landschafts-Bewertung mit Bienen und Wespen in Nisthilfen: Artenspektrum, Interaktionen und Bestimmungsschlüssel. Veröffentlichungen für Naturschutz und Landschaftspflege Baden-Württemberg 27, 277-305.

Gathmann, A., and Tscharntke, T. (2002). Foraging ranges of solitary bees. J. Anim. Ecol. 71 757-764. doi: 10.1046/j.1365-2656.2002.00641.x

Gols, R., Bukovinszky, T., Hemerik, L., Harvey, J. A., Lenteren, J. C., and Vet, L. E. M. (2005). Reduced foraging efficiency of a parasitoid under habitat complexity: implications for population stability and species coexistence. J. Anim. Ecol. 74, 1059-1068. doi: 10.1111/j.1365-2656.2005.01003.x

Griffin, J. N., De La Haye, K. L., Hawkins, S. J., Thompson, R. C., and Jenkins, S. R. (2008). Predator diversity and ecosystem functioning: Density modifies the effect of resource partitioning. Ecology 89, 298-305. doi: 10.1890/07-1220.1 
Hadley, A. S., and Betts, M. G. (2011). The effects of landscape fragmentation on pollination dynamics: absence of evidence not evidence of absence. Biol. Rev. Camb. Philos. Soc. 87, 526-544. doi: 10.1111/j.1469-185X.2011.00205.x

Hagen, M., Kissling, W. D., Rasmussen, C., Aguiar, M. A. M., Brown, L. E., Carstensen, D. W., et al. (2012). Biodiversity, species interactions and ecological networks in a fragmented world. Adv. Ecol. Res. 46, 89-210. doi: 10.1016/B9780-12-396992-7.00002-2

Herrera, J. M., and Doblas-Miranda, E. (2013). Land-cover change effects on trophic interactions: Current knowledge and future challenges in research and conservation. Basic App. Ecol. 14, 1-11. doi: 10.1016/j.baae.2012.11.008

Herrmann, J. D. Kormann U., Schüepp C., Stocker Y., Herzog F. and Entling M. H. (2012). Effects of habitat isolation and predation pressure on an arboreal food-web. Community Ecol. 13, 82-87. doi: 10.1556/ComEc.13.2012.1.10

Hillebrand, H., and Cardinale, B. J. (2004). Consumer effects decline with prey diversity. Ecol. Lett. 7, 192-201. doi: 10.1111/j.1461-0248.2004.00570.x

Holt, R. D., Lawton, J. H., Polis, G. A. and Martinez, N. D. (1999). Trophic rank and the species-area relationship. Ecology 80, 1495-1504. doi: 10.2307/ 176542

Kremen, C., Williams, N. M., Aizen, M. A., Gemmill-Herren, B., LeBuhn, G., Minckley, R., et al. (2007). Pollination and other ecosystem services produced by mobile organisms: a conceptual framework for the effects of land-use change. Ecol. Lett. 10, 299-314. doi: 10.1111/j.1461-0248.2007.01018.x

Kruess, A., and Tscharntke, T. (1994). Habitat fragmentation, species loss, and biological control. Science 264, 1581-1584. doi: 10.1126/science.264. 5165.1581

Kruess, A., and Tscharntke, T. (2000). Species richness and parasitism in a fragmented landscape: experiments and field studies with insects on Vicia sepium. Oecologia 122, 129-137. doi: 10.1007/PL00008829

Laliberté, E., and Tylianakis, J. M. (2010). Deforestation homogenizes tropical parasitoid-host networks. Ecology 91, 1740-1747. doi: 10.1890/09-1328.1

Mortelliti, A., Amori, G., Capizzi, D., Cervone, C., Fagiani, S., Pollini, B., et al. (2011). Independent effects of habitat loss, habitat fragmentation and structural connectivity on the distribution of two arboreal rodents. J. Appl. Ecol. 48, 153-162. doi: 10.1111/j.1365-2664.2010.01918.x

R Development Core Team. (2011). R: A language and environment for statistical computing. R Foundation for Statistical Computing, Vienna, Austria. ISBN 3900051-07-0. Available online at: http://www.R-project.org

Rodriguez, M. A., and Hawkins, B. A. (2000). Diversity, function and stability in parasitoid communities. Ecol. Lett. 3, 35-40. doi: 10.1046/j.14610248.2000.00115.x

Rohlfs, M., and Hoffmeister, T. S. (2004). Are there genetically controlled habitatspecific differences in spatial aggregation of drosophilids? Popul. Ecol. 46, 269-274. doi: 10.1007/s10144-004-0193-9

Rösch, V., Tscharntke, T., Scherber, C., and Batáry, P. (2013). Landscape composition, connectivity and fragment size drive effects of grassland fragmentation on insect communities. J. Appl. Ecol. doi: 10.1111/1365-2664.12056

Rosenheim, J. A. (1990). Density-dependent parasitism and the evolution of aggregated nesting in the solitary Hymenoptera. Ann. Entomol. Soc. Am. 83, 277-286.

Schüepp, C., Herrmann, J. D., Herzog, F., and Schmidt-Entling, M. H. (2011). Differential effects of habitat isolation and landscape composition on wasps, bees, and their enemies. Oecologia 165, 713-721. doi: 10.1007/s00442-0101746-6

Schüepp, C., Herzog, F., and Entling, M. H. (2014a). Disentangling multiple drivers of pollination in a landscape-scale experiment. Proc. R. Soc. B 281: 20132667. doi: $10.1098 /$ rspb.2013.2667

Schüepp, C., Uzman, D., Herzog, F., and Entling, M. H. (2014b). Habitat isolation affects plant-herbivore-enemy interactions on cherry trees. Biological Control, 71, 56-64. doi: 10.1016/j.biocontrol.2014.01.007

Sih, A., Englund, G., and Wooster, D. (1998). Emergent impacts of multiple predators on prey. Trends Ecol Evol, 13, 350-355. doi: 10.1016/S0169-5347(98) 01437-2
Sivakoff, F. S., Rosenheim, J. A., and Hagler, J. R. (2012). Relative dispersal ability of a key agricultural pest and its predators in an annual agroecosystem. Biol. Control 63, 296-303. doi: 10.1016/j.biocontrol.2012.09.008

Staddon, P., Lindo, Z., Crittenden, P. D., Gilbert, F., and Gonzalez, A. (2010). Connectivity, non-random extinction and ecosystem function in experimental metacommunities. Ecol. Lett. 13, 543-552. doi: 10.1111/j.14610248.2010.01450.x

Stamp, N. E. (2001). Effects of prey quantity and quality on predatory wasps. Ecol. Entomol. 26, 292-301. doi: 10.1046/j.1365-2311.2001.00325.x

Steffan-Dewenter, I., and Schiele, S. (2008). Do resources or natural enemies drive bee population dynamics in fragmented habitats? Ecology 89, 1375-1387. doi: 10.1890/06-1323.1

Tscharntke, T., Tylianakis, J. M., Rand, T. A., Didham, R. K., Fahrig, L., Batáry P., et al. (2012). Landscape moderation of biodiversity patterns and processes eight hypotheses. Biol. Rev. Camb. Philos. Soc. 87, 661-685. doi: 10.1111/j.1469185X.2011.00216.x

Tylianakis, J. M. (2013). The global plight of pollinators. Science 339, 1532-1533. doi: $10.1126 /$ science. 1235464

Tylianakis, J. M., and Romo, C. M. (2010). Natural enemy diversity and biological control: making sense of the context-dependency. Basic Appl. Ecol. 11, 657-668. doi: 10.1016/j.baae.2010.08.005

Tylianakis, J. M., Tscharntke, T., and Klein, A.-M. (2006). Diversity, ecosystem function, and stability of parasitoid-host interactions across a tropical habitat gradient. Ecology 87, 3047-3057. doi: 10.1890/0012-9658(2006)87[3047: DEFASO]2.0.CO;2

Tylianakis, J. M., Tscharntke, T., and Lewis, O. T. (2007). Habitat modification alters the structure of tropical host-parasitoid food webs. Nature 445, 202-205. doi: 10.1038 /nature05429

Valladares, G., Cagnolo, L., and Salvo, A. (2012). Forest fragmentation leads to food web contraction. Oikos 121, 299-305. doi: 10.1111/j.1600-0706.2011. 19671.x

Van Nouhuys, S., and Hanski, I. (2002). Colonization rates and distances of a host butterfly and two specific parasitoids in a fragmented landscape. J. An. Ecol. 71, 639-650. doi: 10.1046/j.1365-2656.2002.00627.x

Visser, U., Wiegand, K., Grimm, V., and Johst, K. (2009). Conservation biocontrol in fragmented landscapes: persistence and parasitation in a hostparasitoid model. The Open Ecol. J. 2, 52-61. doi: 10.2174/18742130009020 10052

With, K. A., and Pavuk, D. M. (2011). Habitat area trumps fragmentation effects on arthropods in an experimental landscape system. Landscape Ecol. 26, 1035-1048. doi: 10.1007/s10980-011-9627-x

Zurbuchen, A., Cheesman, S., Klaiber, J., Müller, A., Hein, S., and Dorn, S. (2010). Maximum foraging ranges in solitary bees: only a few individuals have the capability to cover long foraging distances. Biol. Cons. 143, 669-676. doi: 10.1016/j.biocon.2009.12.003

Conflict of Interest Statement: The authors declare that the research was conducted in the absence of any commercial or financial relationships that could be construed as a potential conflict of interest.

Received: 05 March 2014; accepted: 12 June 2014; published online: 30 June 2014. Citation: Coudrain V, Schüepp C, Herzog F, Albrecht M and Entling MH (2014) Habitat amount modulates the effect of patch isolation on host-parasitoid interactions. Front. Environ. Sci. 2:27. doi: 10.3389/fenvs.2014.00027

This article was submitted to Agroecology and Land Use Systems, a section of the journal Frontiers in Environmental Science.

Copyright (C) 2014 Coudrain, Schüepp, Herzog, Albrecht and Entling. This is an openaccess article distributed under the terms of the Creative Commons Attribution License (CC BY). The use, distribution or reproduction in other forums is permitted, provided the original author(s) or licensor are credited and that the original publication in this journal is cited, in accordance with accepted academic practice. No use, distribution or reproduction is permitted which does not comply with these terms. 